\title{
Campur Kode dan Struktur Bahasa Madura pada Tugas Menulis Teks Berita Siswa Kelas 8 SMP Negeri 1 Mayang
}

\author{
Noviarini Indah Astuti ${ }^{1}$, Akhmad Sofyan², Ali Badrudin ${ }^{3}$ \\ Fakultas IImu Budaya, Program Studi Magister Linguistik, Universitas Jember \\ Email: novairinindahastuti@yahoo.com
}

\begin{abstract}
Abstrak: Penelitian ini bertujuan untuk mendeskripsikan wujud campur kode yang ditemukan pada hasil menulis teks berita dan struktur Bahasa Madura yang digunakan campur kode pada tugas menulis teks berita. Data yang digunakan dalam penelitian ini berupa kata yang mengindikasikan adanya wujud campur kode Bahasa Indonesia dan Bahasa Madura pada tugas menulis teks berita. Pada penelitian ini ditemukan fenomena campur kode dan penggunaan struktur Bahasa Madura dalam tugas menulis kembali teks berita yang telah dibaca. Wujud campur kode yang ditemukan

Tersedia Online di

http://journal.unublitar.ac.id/pendidikan/index.php/ Riset_Konseptual

\section{Sejarah Artikel}

Diterima pada : 28-11-2021

Disetuji pada : 30-01-2021

Dipublikasikan pada : 31-01-2021

Kata Kunci:

Campur Kode, Teks Berita, Bahasa Madura

DOI:

http://doi.org/10.28926/riset_konseptual.v5i1.332 pada tugas menulis teks berita siswa kelas 8 SMP Negeri 1 Mayang meliputi 1) campur kode berwujud kata berupa campur kode berwujud kata kerja, kata sifat, kata benda, kata tugas, dan 2) campur kode berwujud frasa. Struktur bahasa Madura yang ditemukan pada tugas menulis teks berita siswa kelas 8 SMP Negeri 1 Mayang anataralain 1) bentuk ulang/ reduplikasi, 2) konstruksi posesif, 3) konstruksi imperatif, 4) konstruksi "berlagak seperti orang...", serta 5) morfofonemik prefiks $N$-.
\end{abstract}

\section{PENDAHULUAN}

Bahasa merupakan alat komunikasi dalam masyarakat dan cermin kebudayaan suatu bangsa. Indonesia mempunyai beraneka ragam budaya, hal ini berpengaruh terhadap ragam bahasa yang digunakan masyarakat. Sebagian besar masyarakat Indonesia tidak hanya mampu menggunakan Bahasa Indonesia (B1), namun mereka juga menguasai bahasa daerah (B2). Fenomena ini dapat disebut kedwibahasaan. Dwibahasa adalah penguasaan seseorang terhadap dua bahasa yang digunakan saat berkomunikasi. Dwibahasa merupakan salah satu kemampuan seseorang untuk menggunakan tuturan dua bahasa yang lengkap dan mempunyai makna. Penutur yang menggunakan dua bahasa atau lebih disinyalir mengalami kontak bahasa. Kontak bahasa adalah pemakaian dua bahasa atau lebih yang digunakan secara bergantian oleh seseorang saat berkomunikasi. Oleh sebab itu, kontak bahasa dapat memicu peristiwa kebahasaan seperti alih kode, peminjaman kata, interferensi dan campur kode. Fokus penelitian ini adalah masalah campur kode.

Bahasa dapat disebut sistem lambang bunyi yang dapat digunakan masyarakat untuk bekerjasama, berinteraksi, dan mengidentifikasi dalam bentuk komunikasi, tingkah laku, dan sopan santun yang baik dan telah disetujui oleh kelompok masyarakat tersebut. Bahasa Madura (BM) adalah bahasa daerah yang digunakan untuk komunikasi oleh masyarakat etnik Madura, baik yang bertempat tinggal di Madura, di pulau kecil sekitar Pulau Madura, dan di perantauan (Sofyan, 2008: 01).

Sebagian besar penutur BM bertempat tinggal di luar Pulau Madura, sedangkan sekitar 35 persen tinggal di Pulau Madura dan pulau kecil sekitarnya (Sofyan, 2008: 02). Berdasarkan data tersebut, dapat disimpulkan bahwa pengguna 
BM cukup banyak, didukung dengan masih terpeliharanya kesenian yang berasal dari Pulau Madura, seperti bângsalan dan paparèghân, saloka, mamaca, lok-alok, tembhâng, sy'ir, wayang kulit, topeng, dan ludruk (Sofyan, 2001; Bouvier, 2002; Imron, 2005). Bahasa Madura erat kaitannya dengan etnik Madura. Menurut Koenjananingrat (2007), etnik dapat dilihat dari adanya persamaan asal-usul yang dapat menimbulkan suatu ikatan. Etnik atau suku merupakan kesatuan ikatan sosial yang berbeda dengan ikatan sosial lainnya. Etnik dapat terikat dengan kesadaran dan identitas yang sama dan diperkuat dengan kesatuan bahasa.

Pada penelitian ini, etnik yang melekat pada subjek ialah etnik Madura. Hal ini dapat terlihat dari bahasa komunikasi yang digunakan dalam lingkup kecil yaitu keluarga. Terlihat dari angket yang dibagikan, sebagian besar siswa menggunakan Bahasa Madura sebagai bahasa komunikasi yang digunakan dalam keseharian. Selain itu, berdasarkan wawancara yang dilakukan, siswa dan keluarganya masih ada hubungan kedekatan dengan masyarakat Pulau Madura, selain itu mereka juga merupakan pendatang dari Pulau Madura yang bertransmigrasi sejak dahulu kala.

Pada Bahasa Madura, strukutur kalimat khususnya morfologi masih menjadi masalah yang belum terpecahkan. Menurut Sofyan (2005) kajian yang dilakukan selama ini hanya berisi deskripsi secara umum dan tidak mengungkapkan bagian yang bermasalah tersebut. Sofyan (2001) mengungkapkan bahwa ada keunikan pada kontruksti imperatif dalam BM.

Suatu fenomena dalam bahasa adalah campur kode, yaitu adanya unsur bahasa lain kedalam unsur bahasa tertentu. Campur kode dapat terjadi apabila penutur mempunyai latar belakang bahasa yang berbeda antara bahasa satu dengan yang lain. Contoh campur kode salah satunya yaitu adanya unsur Bahasa Madura dalam tugas menulis Bahasa Indonesia yang terjadi pada siswa sekolah menengah di Kabupaten Jember.

Kabupaten Jember merupakan sebuah kabupaten di Jawa Timur yang memiliki keragaman masyarakat dan budaya. Mayang adalah salah satu kecamatan di Kabupaten Jember dengan masyarakat yang aktif menggunakan Bahasa Madura sebagai bahasa kedua setelah Bahasa Indonesia. Penggunaan Bahasa Madura (BM) di Kecamatan Mayang menjadi bahasa komunikasi sehari-hari masyarakat setempat.

Penggunaan Bahasa Madura (BM) tidak hanya terbatas pada situasi nonformal saja, tetapi juga situasi formal. Penggunaan Bahasa Madura dalam situasi nonfromal contohnya dalam keluarga sedangkan penggunaan Bahasa Madura pada situasi formal dapat dijumpai di sekolah. Bahasa Madura (BM) digunakan dalam lingkungan keluarga maupun sekolah, hal ini menimbulkan kesulitan untuk menguasai Bahasa Indonesia (BI) ketika berada di sekolah menengah.

Pembelajaran Bahasa Indonesia erat kaitannya dengan pembelajaran tata bahasa Bahasa Indonesia. Mata pelajaran Bahasa Indonesia diorientasikan kepada pembelajaran berbasis teks. Pembelajaran berbasis teks mengajarkan kepada siswa supaya mampu menggunakan teks sesuai tujuan sosial teks yang dipelajarinya (Mahsun, 2014). Salah satu tujuan sosial teks terdapat pada makna dalam teks yang sedang dipelajari, sehingga guru harus mengajarkan secara menyeluruh. Salah satu teks yang dipelajari dalam Kurikulum 2013 adalah teks berita. Teks berita adalah teks yang berisi laporan suatu peritiwa terbaru yang terjadi secara nyata, bersifat penting untuk dilaporkan kepada pembaca, serta menarik bagi pembaca. Menurut Sumadiria $(2005: 65)$ berita merupakan suatu laporan peritiwa tercepat mengenai fakta terbaru yang benar, penting, dan menarik.

Keterampilan menulis merupakan salah satu aspek dalam keterampilan berbahasa yang mencangkup keterampilan berbicara, menyimak, membaca, dan menulis (Tarigan, 1990: 2). Keterampilan menulis merupakan keterampilan berbahasa yang menuntut siswa mampu mengonstruksi pikirannya dengan baik mengenai suatu konsep dan mampu menuangkannya dalam bentuk tulisan. Menulis dapat menciptakan kreatifitas dan mengembangkan ide-ide inovatif. Demikian pula dengan menulis kembali teks berita yang telah dibaca seperti yang dilakukan siswa pada penelitian ini. 
Pada materi teks berita, terdapat kompetesi dasar (KD) menuliskan kembali berita yang dibaca ke dalam beberapa kalimat. Pada KD ini, siswa diharap dapat memproduksi atau membuat teks berita dengan menggunakan Bahasa Indonesia. Berdasarkan observasi awal yang dilakukan, ditemukan fenomena campur kode dalam tugas menulis kembali teks berita yang telah dibaca. Hal ini dapat terlihat pada penggunaan struktur morfologis Bahasa Madura (BM) pada kalimat Bahasa Indonesia (BI) dan wujud campur kode yang digunakan, diduga hal ini terjadi karena ketidakmampuan siswa mengubah Bahasa Madura (BM) yang dikuasai menjadi Bahasa Indonesia (BI) yang digunakan secara formal.

Pada pembelajaran Bahasa Indoonesia di sekolah, siswa dituntut untuk mengerti teori bahasa dan fasih dalam menggunakan Bahasa Indonesia. Namun, hal ini kurang terwujud karena siswa dominan menggunakan bahasa daerah dan bahasa ibu dalam pembelajaran, begitu juga pada tugas menulis. Berdasarkan penjelasan tersebut, dipilih judul penelitian yaitu "Campur Kode dan Struktur Bahasa Madura pada Tugas Menulis Teks Berita Siswa Kelas 8 SMP Negeri 1 Mayang."

\section{METODE}

Penelitian ini bertujuan untuk mendeskripsikan wujud campur kode yang ditemukan pada hasil menulis teks berita siswa kelas 8 SMP Negeri 1 Mayang dan mendeskripsikan struktur Bahasa Madura yang digunakan campur kode pada tugas menulis teks berita siswa kelas 8 SMP Negeri 1 Mayang. Rancangan yang digunakan pada penelitian ini adalah penelitian kualitatif, penelitian kualitatif merupakan penelitian dengan sasaran penelitian yang terbatas, tetapi dengan keterbatasan sasaran penelitian yang ada akan digali sebanyak mungkin data mengenai sasaran penelitian.

Campur kode yang akan diteliti dalam penelitian ini adalah campur kode dalam Bahasa Madura. Melalui observasi di sekolah-sekolah, terpilih SMP Negeri 1 Mayang sebagai tempat penelitian dan objek yang digunakan adalah teks berita siswa etnik Madura kelas 8 SMP Negeri 1 Mayang. Subjek yang digunakan adalah siswa yang ber etnik Madura, untuk mengetahui bahwa subjek penelitian merupakan etnik Madura, peneliti meggunakan angket untuk mendata subjek.

Rumusan masalah yang dibuat dalam penelitian ini yaitu 1) wujud campur kode pada tugas menulis teks berita siswa etnik Madura kelas 8 SMP Negeri 1 Mayang, 2) mengetahui struktur Bahasa Madura yang digunakan dengan bantuan menggunakan tabel 2.1 keunikan struktur atau pola urutan (Sofyan, 2008: 133) serta3) faktor yang menyebabkan adanya campur kode Bahasa Madura pada hasil menulis teks berita.

Data yang digunakan dalam penelitian ini berupa kata yang mengindikasikan adanya wujud campur kode Bahasa Indonesia dan Bahasa Madura pada tugas menulis teks berita yang dilakukan siswa etnik Madura kelas 8 SMP Negeri 1 Mayang. Penelitian ini juga menggunakan angket yang diisi oleh subjek penelitian. Subjek pada penelitian ini adalah siswa kelas 8 SMP Negeri 1 Mayang.

\section{HASIL DAN PEMBAHASAN}

\section{Wujud Campur Kode}

Wujud campur kode yang ditemukan yaitu campur kode berwujud kata, campur kode berwujud frasa, campur kode berwujud klausa, campur kode berwujud baster, dan campur kode berwujud idiom.

A. Campur Kode Berwujud Kata

1. Campur Kode Berwujud Kata Kerja

(1) Penyaket "se nyerang" manusah ben keben juga bisa esebabkan oleh penyaket hanya bisa hidup jika mereka menempel e inangnya.

\section{(CKBK-Kk 1-A)}


Pada data (1) terdapat campur kode BM, yaitu kata "se nyerang" yang berarti yang menyerang dalam BI. Data ini dapat dikategorikan pada campur kode berwujud kata kerja, untuk mengenali jenis kata kerja dapat diibuktikan dengan menambah KB (kata benda) atau KS (kata sifat) di belakangan kata yang diuji. KB yang ditambahkan yaitu kata manusah (BM) atau manusia (BI).

(2) Fag sebenarnya fag sudah egunakagin untuk "ngobateh" penyaket. (CKBK-Kk 2A)

Pada data (2) terdapat campur kode BM, yaitu kata "ngobateh" (BM) yang berarti mengobati. Mengobati adalah kegiatan seseorang untuk menyembuhkan, berarti mengobati dapat diikategorikan kata kerja. Untuk menguji jenis kata kerja dapat diibuktikan dengan menambah KB (kata benda) atau KS (kata sifat) di belakangan kata yang diuji. KB yang ditambahkan yaitu kata penyaket.

(3) Cara "se elakonin" oleh virus ini ternyatah berfungsi sebagai sala settong cara mereka bertahan hidup. (CKBK-Kk 6-A)

Pada data (3) terdapat campur kode BM, yaitu kata "se elakonin" (BM) yang berarti yang dilakukan (BI). Bila masuk dalam kalimat, "se elakonin" (BM) merupakan kata kerja yang berfungsi sebagai predikat dalam kalimat.

Data (1), (2), dan (3) menunjukkan adanya campur kode yang dilakukan siswa terhadap tugas menulis teks berita. Campur kode yang dilakukan berwujud kata kerja dalam Bahasa Madura yang disisipkan pada kalimat Bahasa Indonesia untuk membuat kalimat menjadi bermakna dan pesan tersampaikan kepada pembaca.

2. Campur Kode Berwujud Kata Sifat

(4) Virus adalah mikroorganisme aropah parasit "se tak padheng" ben bisa tombu serta odik di tubuh inangnya. (CKBK-Ks 9-C)

Pada data (4) terdapat campur kode berwujud kata sifat yaitu "se tak padheng" yang mempunyai arti yang tidak kelihatan. Data (4) dapat dikategorikan campur kode berwujud kata sifat karena mempunyai ciri bergabung dengan ta' 'tidak'.

(5) Virus adalah mikroorganisme aropah parasit se tak apdheng ben bisa "tombu" serta odik di tubuh inangnya. (CKBK-Ks 11-C)

Pada data (5) ditemukan campur kode berwujud kata sifat yaitu "tombu" (BM) yang berarti tumbuh (BI). Kata "tombu" dikategorikan kata sifat/ adjektiva dasar karena merupakan kata dasar yang telah memiliki makna.

Data (4) dan (5) menunjukkan adanya campur kode berwujud kata sifat yang dilakukan siswa pada tugas menulis teks berita. Campur kode berwujud kata sifat yang ditemukan berupa penggunaan "ta" yang merupakan ciri dari adjektiva dalam Bahasa Madura. Selain itu, wujud campur kode berwujud kata sifat yang konkret.

3. Campur Kode Berwujud Kata Benda

Berikut data yang ditemukan pada tugas menulis teks berita.

(6)

Virus fag bisa di dapatkan derih berbagai "kennengan". (CKBK-Kb

4-A)

Pada data (6) terdapat campur kode berwujud kata benda yaitu "kennengan" (BM) yang berarti tempat $(\mathrm{BI})$. Kata tempat yang dimaksud dalam data tersebut, merupakan tempat yang bermakna sesungguhnya. Kata "kennengan" pada kalimat tersebut berfungsi sebagai pelengkap karena predikat dalam kalimat tersebut berupa verba.

poteh" (CKBK-Kb 5-A)

Sel tumor, sel-sel pembunuh alami manusah yaitu jenis sel "dereh

Pada data (7), ditemukan campur kode berwujud benda yaitu pada kata "dereh poteh" (BM) yang berarti darah putih (BI). Darah putih yang dimaksud adalah darah yang ada dalam tubuh, menggunakan makna yang sesungguhnya. Darah dikategorikan sebagai benda. Namun, penulisan dalam tugas menulis tersebut diubah menjadi penulisan sesuai pengucapan bahasa Madura.

(8)

Contoh virus lainnya yang bisa alindungin "bedhen" derih penyakit adalah virus herpes laten. (CKBK-Kb 13-C)

Pada data (8), ditemukan data campur kode berwujud benda yaitu "bedhen" (BM) yang berarti badan menggunakan makna sesuatu benda yang konkret. Namun, 
penulisannya menggunakan Bahasa Madura untuk mempermudah menyampaikan pesan pada tulisan.

(9)

Virus fag bisa eolleagih derih berbagai tempat "aing", kotoran, limbah, bik laenah. (CKBK-Kb 17-D)

Pada data (9), terdapat campur kode berwujud benda yaitu "aing" (BM) yang berarti air (BI). Air dapat dikategorikan sebagai benda yang konkret. Kalimat yang ditulis menunjukkan bahwa virus fag bisa ditemukan di tempat air, kotoran, limbah, dan lain-lain. Namun, penulisannya menggunakan Bahasa Madura untuk mempermudah menyampaikan pesan dalam kalimat.

(10) Ternyata ada jenis virus ebisa melindungi "tang tubuh" dan mengetahui penyaket. (CKBK-Kb 19-F)

Pada data (10), ditemukan campur kode berwujud benda yaitu pada kata "tang tubuh" (BM) yang berarti tubuh saya (BI). Tubuh yang dimaksud adalah darah yang ada dalam tubuh, menggunakan makna yang sesungguhnya. Tubuh dikategorikan sebagai benda. Namun, penulisan dalam tugas menulis tersebut diubah menjadi penulisan sesuai pengucapan bahasa Madura.

Data (6), (7), (8), (9), dan (10) membuktikan bahwa terdapat campur kode berwujud kata benda yang terdapat pada tugas menulis siswa. Ciri-ciri yang menunjukkan kata benda dapat diikuti "tang" (BM) yang artinya ku- atau menunjukkan kepemilikan. Selain itu, juga terdapat kata benda yang konkret seperti tubuh, air, darah putih, dan tempat.

4. Campur Kode Berwujud Kata Tugas

Kata tugas ada lima, yaitu preposisi, konjungsi, interjeksi, artikulus, dan kategori fatis. Presposisi adalah kata depan yang letaknya selalu berada di depan kata benda, kata sifat, kata kerja, dan untuk membentuk gabungan kata depan. Konjungsi adalah kata tugas yang berfungsi sebagai penghubung dua kata atau dua kalimat. Interjeksi adalah kata tugas yang dipakai untuk mengungkapkan seruan seperti rasa kagum, sedih, heran, dan jijik. Artikulus dalah kata sandang yang mempunyai fungsi sebagai penentu sesuatu nomina, adjektiva, atau kelas lain (dalam Chaer, 2010: 104). Berikut data yang ditemukan pada tugas menulis teks berita siswa kelas 8 SMP Negeri 1 Mayang.

(11) Virus fag bisa di dapatkan "derih" berbagai kennengan. (CKBK-Kt 4-A)

Pada data (11), ditemukan adanya campur kode Bahasa Madura berwujud kata tugas. Jenis kata tugas yang digunakan yaitu konjungsi "derih" (BM) yang berarti dari (BI). Kata "derih" digunakan sebagai penghubung kata agar kalimat bermakna.

(12) Cara yang "e" gunakagin virus herpes bertahan hidup di dalam tubuh inangnya. (CKBK-Kt 7-B)

Pada data (12), ditemukan adanya campur kode Bahasa Madura berwujud kata tugas. Jenis kata tugas yang digunakan yaitu preposisi atau kata depan " $e$ " yang berarti di-. Preposisi "e" berada di depan kata kerja "gunakagin" untuk membentuk gabungan kata depan. Bila digabungkan mempunyai arti digunakan (BI).

(13) Virus adalah mikroorganisme "aropah" parasit se tak padheng ben bisa tombu serta odik di tubuh inangnya. (CKBK-Kt 8-C)

Pada data (13), ditemukan adanya campur kode Bahasa Madura berwujud kata tugas. Jenis kata tugas yang digunakan yaitu konjungsi untuk menerangkan kata sebelumnya agar bermakna.

(14) Virus adalah mikroorganisme aropah parasit se tak apdheng "ben" bisa tombu serta odik di tubuh inangnya. (CKBK-Kt 10-C)

Pada data (14), ditemukan campur kode Bahasa Madura pada kata "ben" (BM) yang berwujud kata tugas. Jenis kata tugas yang digunakan adalah konjungsi "ben" (BM) yang artinya dan(BI). Kata dan digunakan untuk menggabungkan dua kata agar bermakna.

(15) Contoh virus lainnya yang bisa " $a$ " lindungin bedhen derih penyakit adalah virus herpes laten. (CKBK-Kt 12-C) 
Pada data (15), ditemukan campur kode Bahsa Madura yang berwujud kata tugas yang berjenis preposisi. Kata "a" (BM) yang berarti me- $(\mathrm{BI})$ merupakan preposisi atau kata depan yang diikuti kata "lindungin" (BM). Bila digabung menjadi "a lindungin" (BM) yang berarti melindungi.

(16) Virus fag bisa "e" olleagih derih berbagai tempat aing, kotoran, limbah, bik laenah. (CKBK-Kt 14-D)

Pada data (16), ditemukan adanya campur kode Bahasa Madura berwujud kata tugas. Jenis kata tugas yang digunakan yaitu preposisi atau kata depan " $e$ " yang berarti di-. Preposisi "e" berada di depan kata kerja "olleagih" (BM). Kata "olleagih" $(\mathrm{BM})$ yang berarti dapat (BI) diberi kata depan "e" (BM) untuk membentuk gabungan kata depan. Bila digabungkan mempunyai arti didapat (BI).

(17) Virus fag bisa eolleagih "derih" berbagai tempat aing, kotoran, limbah, bik laenah. (CKBK-Kt 15-D)

Pada data (17), ditemukan adanya campur kode berwujud kata tugas yang berjenis preposisi. Kata "derih" (BM) yang berarti dari (BI) merupakan preposisi untuuk membentuk gabungan kata depan.

(18) Virus fag bisa eolleagih derih berbagai tempat aing, kotoran, limbah, "bik" laenah. (CKBK-Kt 16-D)

Pada data (18), ditemukan adanya campur kode berwujud kata tugas yang berjenis konjungsi. Kata "bik" (BM) yang berarti dan (BI) merupakan konjungsi penambahan.

(19) Virus "gun" bisa berkembang biak jika mereka memilki atau menempul di inangnya. (CKBK-Kt 17-E)

Pada data (19), ditemukan campur kode Bahasa Madura berwujud kata tugas yang berjenis konjungsi. Kata "gun" (BM) yang berarti hanya (BI) digunakan sebagai kata penghubung untuk menjelaskan syarat.

(20) Lendir ini a gunah "gebhey" pelindung serat penghalang terhadap bakteri.

\section{(CKBK-Kt 20-F)}

Pada data (20), ditemukan campur kode Bahasa Madura berwujud kata tugas. Jenis kata tugas yang ditemukan yaitu konjungsi. Kata "gebhey" (BM) yang berarti untuk $(\mathrm{BI})$ merupakan kata konjungsi yang digunakan untuk menghubungkan dua kata untuk menyatakan sasaran.

B. Campur Kode Berwujud Frasa

Maksud dari campur kode berwujud frasa adalah jika seorang penutur sering menggunakan dengan memasukkan unsur bahasa tersebut ke dalam tuturannya. Pada hasil tugas menulis siswa, ditemukan 2 data campur kode yang berwujud frasa.

(21) Sel tumor, sel-sel pembunuh alami manusah yaitu jenis sel "dereh poteh".

\section{(CKBF 21-A)}

Pada data (21), ditemukan campur kode yang berwujud frasa. Data (21) menunjukkan frasa, dua gabungan kata tersebut tidak mempunyai predikat sehingga dapat dikategorikan sebagai campur kode berwujud frasa. Kata "dereh poteh" (BM) mempunyai arti darah putih (BI).

(22) Cara se elakonin oleh virus ini ternayatah berfungsi sebagai "sala settong" cara bertahan odik. (CKBF 22-A)

Pada data (22), ditemukan campur kode yang berwujud frasa. Data (22) menunjukkan frasa, dua gabungan kata tersebut tidak mempunyai predikat sehingga dapat dikategorikan sebagai campur kode berwujud frasa. Kata "sala settong" (BM) mempunyai arti salah satu (BI).

\section{Struktur atau Pola Bahasa Madura}

Berdasarkan data yang ada pada tugas menulis teks berita siswa kelas 8 SMP Negeri 1 Mayang, ditemukan adanya campur kode Bahasa Madura ke dalam Bahasa Indonesia. Struktur Bahasa Madura dicari dengan menggunakan tabel 2.1 keunikan struktur atau pola urutan (Sofyan, 2008: 133).

1. Bentuk ulang/reduplikasi 
Bentuk ulang atau reduplikasi ditemukan pada tugas menulis teks berita. Sebagian besar reduplikasi yang ditemukan dalam tugas menulis siswa hanya pada suku akhir saja.

(1) Virus fag bisa didapatkan dari berbagai kennengan seperti air, kotoran, angin, ben "en-laen". (BU 2-A)

Pada data (1), ditemukan adanya campur kode Bahasa madura yang menggunakan struktur atau pola bahasa Bahasa Madura. Kata "en-laen" (BM) yang mempunyai arti lain-lain (BI) menggunakan struktur reduplikasi atau menggunakan bentuk ulang. Reduplikasi merupakan salah satu keunikan stuktur yang sering digunakan orang beretnis Madura. Siswa tersebut menggunakan reduplikasi hanya pada suku akhirnya saja.

(2) Contoh virus lain yang bisa odik, virus juga dari penyakit adalah virus herpes laten yang bisa "long nolongin" sel-sel pembunuh alami manusia. (BU 3-B)

Pada data (2), ditemukan adanya campur kode Bahasa Madura yang menggunakan struktur atau pola bahasa Bahasa Madura. Kata "long-nolongin" (BM) yang mempunyai arti menolong (BI) menggunakan struktur reduplikasi atau menggunakan bentuk ulang. Kata dasar dari "long-nolongi" yaitu "nolong" yang mempunyai arti menolong, diberi imbuhan "-in" untuk menandakan kata kerja. Reduplikasi merupakan salah satu keunikan stuktur yang sering digunakan masyarakat beretnis Madura. Siswa tersebut menggunakan reduplikasi hanya pada suku akhirnya saja.

Data (1) dan (2) menunjukkan, siswa mengggunakan campur kode Bahasa Madura dengan menggunakan struktur reduplikasi atau bentuk ulang. Fenomena ini sering terjadi pada data lain karena reduplikasi merupakan salah satu keunikan struktur yang sering digunakan masyarakat beretnis Madura. Namun, reduplikasi yang digunakan hanya pada suku akhirnya saja.

2. Konstruksi Posesif

Pada Bahasa Madura, penanda posesif untuk struktur orang pertama terbalik dan hampir sama dengan Bahasa Inggris., yaitu persona ditelakkan sebelum nomina (Sofyan, 2008:131). Berikut data yang ditemukan pada tugas menulis siswa.

(3) Ternyata ada jenis virus se bisa melindungi "tang tubuh" dan mengetahui penyaket. (KPo 7-F)

Pada data (3), ditemukan adanya struktur konstruksi posesif. Kata "tang tubuh" (BM) merupakan struktur persona diletakkan sebelum nomina. Persona pada data tersebut yaitu "tang" dan nomina atau kata benda yaitu "tubuh". Kata "tang" menunjukkan kepemilikan aku, jadi "tang tubuh" (BM) dalam Bahasa Indonesia berarti tubuhku.

3. Konstruksi Imperatif

Konstruksi imperatif dalam Bahasa Madura adalah verba berupa bentuk aktif, seperti pada data (4).

(4) Virus fag "bisa olleagih" derih berbagai tempat aing, kotoran, limbah, bik laenah. (KI 5-C)

Pada data (4), kata "bisa olleagih" dapat dikategorikan pada struktur konstruksi imperatif dalam Bahasa Madura. Kata "olleagih" termasuk verba yang berbentuk aktif. 4. Konstruksi "berlagak seperti orang..."

Konstruksi "berlagak seperti orang..." dapat menggunakan konstruksi $\mathrm{R}+m a-+\mathrm{D}$ atau $m a-+R+D$. Pada tugas siswa ditemukan konstruksi jenis ini, berikut data (5).

(5) Virus ini "marik berrik" perlindungan bagi sel pembunuh gellek se memungkinkan mereka terdeteksi penyaket tumor penyabab kanker. (Kbsso 6D)

Pada data (5), ditemukan konstruksi "berlagak seperti orang..." yang menggunakan konstruksi ma-+R+D. Prefiks \{ma-\} berposisi pada bentuk ulang. Kata "marik berik" (BM) yang berarti memberikan (BI) dapat dikategorikan menggunakan struktur $m a-+R+D$.

5. Morfofonemik prefiks $N$ - 
Prefiks $N$ - dapat mempengaruhi fonem awal bentuk dasar (yang berupa konsonan) menjadi luluh. Selain itu, dapat mengakibatkan vokal bentuk dasar menjadi berubah. Prefiks $N$ - bermacam-macam variasinya, seperti varian $m$-, varian $n-$, varian $n y-$, varian $n g$-. Berikut data yang ditemukan.

(6) "Penyakef" yang menyerang manusah ben keben juga bisa disebabkan oleh penyaket hanya bisa hidup jika mereka menempel di inangnya. (MpN- 1-A)

Pada data (6), ditemukan adanya struktur morfofonemik prefiks $N$-. Kata dasar "saket" merupakan fonem awal yang bentuk dasarnya berupa konsonan. Pemberian imbuhan "pe-" mengakiakibatkan kata dasar menjadi menjadi luluh dan berubah menjadi "penyaket".

(7) Virus juga ternyata bisa menginveksi ben "ngancoren" bakteri tertentu. (MpN- 5-C)

Pada data (7), ditemukan adanya struktur morfofonemik prefiks $N$-. Kata "ngancoren" memiliki kata dasar "ancor". Apabila prefiks $N$ - bergabung dengan bentuk dasar yang berfonem awal huruf vokal, maka akan menjadi $n g$-. Sehingga $\mathrm{N}$ - + ancor menjadi "ngancoren".

Berdasarkan data (6) dan (7), prefiks $N$ - dapat mempengaruhi fonem awal bentuk dasar (yang berupa konsonan) menjadi luluh. Selain itu, dapat mengakibatkan vokal bentuk dasar menjadi berubah.

\section{KESIMPULAN}

Berdasarkan data yang ditemukan, dapat disimpulkan bahwa campur kode dalam Bahasa Madura sering digunakan siswa dalam menulis teks berita. Namun,hanya wujud campur kode serta struktur Bahasa Madura tertentu yang digunkan pada saat menulis teks berita. Campur kode yang dilakukan siswa pada tugas menulis berita digunakan untuk mempermudah penyampaian ide pikiran dan maksud yang akan dituliskan. Bahasa Madura yang digunakan sebagian besar dipengaruhi oleh lingkungan keluarga dan sekolah. Intensitas penggunaan Bahasa Madura sangat sering dilakukan, bahkan secara keseluruhan saat berkomunikasi menggunakan Bahasa Madura. Walaupun menggunakan campur kode Bahasa Madura, seluruh siswa ternyata tidak mengetahui bahwa wujud campur kode dan struktur Bahasa Madura yang digunakan dapat dikelompokkan dan dapat menjadi sebuah penelitian.

\section{DAFTAR RUJUKAN}

Abdullah, Alek and Achmad, H. (2012) Linguistik Umum. Jakarta: PT. Erlangga.

Abidin, Y. (2012) Pembelajaran Bahasa Berbasis Pendidikan Karakter. Bandung: Refika Aditama.

Akhadiah, S., Arsjad, M. G., \& Ridwan, S. H. (2012) Pembinaan Kemampuan Menulis Bahasa Indonesia. Jakarta: Erlangga.

Apple, R. (1976) Sociolingustiek. Antwerpen/Utrecht: Het Spectrum.

Arikunto, S. (2000) Manageman Pendidikan. Jakarta: Rineka Cipta.

Bouvier, H. (2002) LEbur! Seni Musik dan Pertunjukan dalam Masyarakat Madura. Jakarta: Yayasan Obor Indonesia.

Bungin, B. (2001) Metodologi Penelitian Sosial: Format-format Kuantitatif dan Kualitatif. Surabaya: Airlangga University Press.

Bungin, B (2001) Strategi Multi Various-Method di dalam Penelitian Media Massa". Dalam Bungin, B. (Ed.). Metode Penelitian Kualitatif: Aktualisasi Metodologis ke Arah Ragam Varian Kontemporer. Jakarta: PT Raja Grafindo Persada.

Bungin, B. (2003) "Metode Trianggulasi". Dalam Bungin, B. (Ed.). Analisis Data Penelitian Kualitatif: Pemahaman Filosofis dan Metodologis ke Arah Penguasaan Model Aplikasi. Jakarta: PT Raja Grafindo Persada.

Chaer (2010) Sosiolinguistik Perkenalan Awal. Jakarta: Rineka Cipta.

Djuraid, H. N. (2006) Panduan Menulis Berita. Malang: UPT Penerbitan Universitas 
Muhamadiyah Malang.

Fauzan (2014) Campur Kode Bahasa Madura ke dalam Bahasa Indonesia dalam Percakapan Mahasiswa di Lingkungan Fakultas Keguruan dan IImu Pendidikan Universitas Jember. Fakultas Keguruan dan IImu Pendidikan Universitas Jember.

Fauziah, A. (2012) Peningkatan Kemampuan Menulis Teks Berita Siswa Kelas VIII SMP Negeri 2 Kencong dengan Strategi ATDRAP. Universitas Negeri Malang.

Fazri, A. (2018) 'Citizen Journalism: Kelayakan Berita Ditinjau Dari Segi Bahasa Dan Etika Jurnalistik.', Jurnal IImu Komunikasi, 2(3).

Finoza, L. (2002) Komposisi Bahasa Indonesia. Jakarta: Diksi Insan Mulia.

Gagne, R. M. (1989) Kondisi Belajar dan Teori Pembelajaran. (terjemah: Munandir). Jakarta: PAU Dirjen Dikti Depdikbud.

Gumperz, J. J. ] and Hymes., D. (1972) The Ethnography of Communication American Antrophologist. New York: Special Publication.

Husna, A. (2013) Campur Kode dalam Karangan Narasi Siswa Kelas VIII MTs (Madrasah Tsanawiyah) Manbaul Ulum Pondok Pesantren Asshiddiqiyah II Bartu Ceper, Tangerang. FITK UIN Syarif Hidayatullah Jakarta).

Imron, D. Z. (2002) Soto Suf dari Madura: Perspektif Spiritualitas Masyarakat Desa. Bandung: Media Cendekia.

Koentjaraningrat (2007) Manusia dan Kebudayaan. Jakarta: Djambatan.

Kridalaksana, H. (1982) Kamus Linguistik. Jakarta: Gramedia.

Mackey, W. F. (1986) Analisis Bahasa. Surabaya: Usaha Nasional.

Mahsun (2014) Teks dalam Pembelajaran Bahasa Indonesia. Jakarta: PT. Raja Grafindo.

Nawawi, H. (1998) Manajemen Sumber Daya Manusia Untuk Bisnis Yang Kompetitif. Yogyakarta: Gajah Mada University Press, cetakan Kedua.

Nuryanti, A. (2017) Campur Kode Pada Teks Deskripsi Sugestif Berbahasa Indonesia Siswa Kelas VII SMP Negeri 1 Jember. Universitas Jember.

Ohoiwutun, P. (2002) Sosiolinguistik: Memahami Bahasa dalam Konteks Masyarakat dan Kebudayaan. Jakarta: Kesaint Blanc.

Rahardi, R. and Kunjana (2001) Serpih-serpih Masalah Kebahasaindonesiaan. Jakarta: Adicipta.

Rasyid, H. and Dkk (2009) Asesmen Perkembangan Anak Usia Dini. Yogyakarta: Multi Presindo.

Siregar, B. U. (2011) SelukBeluk Fungsi Bahasa. Jakarta: Pusat Kajian Bahasa dan Budaya Universitas Katolik Indonesia Atma Jaya.

Sofyan, A. (2008) Variasi, Keunikan, dan Penggunaan Bahasa Madura. Surabaya: Balai Bahasa Surabaya.

Sofyan, A. (2010) 'Beberapa Keunikan Linguistik Bahasa Madura', Jurnal Humaniora, 19(3).

Sofyan, A. (2012) 'Perilaku dan makna verba dalam bahasa Madura', Jurnal Humaniora, 24(3), pp. 333-344.

Sofyan, A. (2016) Bahasa Madura. Yogyakarta: Jogja Bangkit Publisher.

Suhandang, K. (2010) Pengantar Jurnalistik Seputar Organisasi, Produk, dan Kode Etik. Bandung: Nuansa.

Sumadiria, A. H. (2005) Jurnalistik Indonesia, Menulis Berita dan Feature, Panduan Praktis Jurnalis Profesional. Bandung: PT. Remaja Rosdakarya.

Suntoro (2009) Peningkatan Keterampilan Menulis Teks Berita Menggunakan Teknik 3M (Mengamati, Meniru, Dan Menambahi) Pada Siswa KELAS VIII A SMP Negeri 1 Cluwak Pati. Universitas Negeri Semarang.

Susmita, N. (2015) 'Alih kode dan campur kode dalam pembelajaran bahasa Indonesia di SMP Negeri 12 Kerinci', Jurnal Penelitian Universitas Jambi: Seri Humaniora, 17(2).

Suwito (1985) Sosiolinguistik: Pengantar Awal. Surakarta: Henary.

Syamsuri, A. S. (2013) 'Bahasa Indonesia sebagai Penghela Ilmu Pengetahuan dan 
Wahana Iptek: Pembentukan Istilah sebagai Salah Satu Usaha Mewujudkannya.', in Kongres X Bahasa Indonesia, p. 14.

Tarigan, H. G. (1986) Menulis sebagai Suatu Keterampilan Berbahasa. Bandung: Angkasa.

Tarigan, H. G. (1990) Analisis Kesalahan Berbahasa. Jakarta: Departemen Pendidikan dan Kebudayaan. 